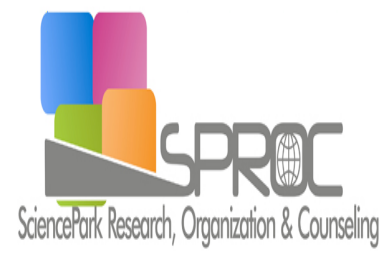

\section{New Trends and Issues Proceedings on Humanities and Social Sciences}

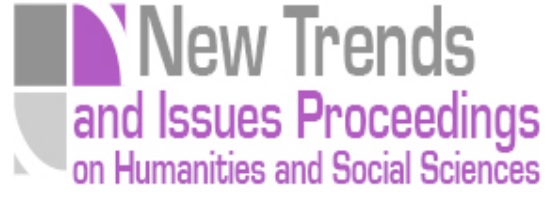

ISSN 2421-8030

www.prosoc.eu

Selected paper of 7th World Conference on Psychology, Counselling and Guidance (WCPCG 2016) 28 - 30 April 2016 , Pine Bay Holiday Resort, Kusadası Izmir, Turkey

\title{
The Concept of Love among Multi-cultures Postgraduate Students at Universiti Teknologi Malaysia
}

Keyvan Mahabadi Ashtiani**, Master of Clinical Psychology, Department of psychology, Roudehen branch, Islamic Azad

Sanaz Goodarzi ${ }^{\mathrm{b}}$, Master of Guidance \& counseling, Department of psychology, Roudehen branch,Islamic Azad

Niloufar Tahghighi Ahmadi', Doctoral Student, Department of Guidance \& Counseling Faculty of Education, Allameh Tabataba'i University

\section{Suggested Citation:}

Mahabadi Ashtiani, K., Goodarzi, S. \& Tahghighi Ahmadi, N. (2017). The Concept of Love among Multi-cultures Postgraduate Students at Universiti Teknologi Malaysia. New Trends and Issues Proceedings on Humanities and Social Sciences. [Online]. 02, pp 88-96. Available from: www.prosoc.eu

Selection and peer review under responsibility of Prof. Dr. Marilyn Campbell, Queensland University of Technology, Australia

${ }^{\circ} 2017$ SciencePark Research, Organization \& Counseling. All rights reserved.

\begin{abstract}
The main purpose of this research was to identify the level of understanding on the concept of love among multi-culturs postgraduate students who were currently studying at Universiti Teknologi Malaysia Johor Bahru campus. The open-ended questionnaires were sent to 30 postgraduate students who were selected based on the purposive sampling method. They comprised of students subscribing to four main culturs, i) Iranian, ii) Malay, iii) Chinese and iv) Indian at Universiti Teknologi Malaysia. Data collected were analyzed using the explicit coding which first similar word or phrases coded and recorded. Each code labeled using the keywords from the words or phrases. Results showed that $80 \%$ of Iranian students defined love as sacrifice and devotion for lover. In contrast, $70 \%$ of Malaysian students referred the concept of love as an appreciation that God has been given, while $80 \%$ of Chinese students referred the concept of love as commitment and loyalty and $80 \%$ of Indian student's defined love as love is life.
\end{abstract}

Keywords: concept of love; definition; multi-cultures; postgraduate student; Iranian; Malaysian; Chinese; Indian

\footnotetext{
* AdDRESS FOR CORRESPONDENCE: Keyvan Mahabadi Ashtiani, Master of Clinical Psychology, Department of psychology, Roudehen branch, Islamic Azad

E-mail address: sharghy20020@yahoo.com / Tel.: +98-912-227-9707
} 
Mahabadi Ashtiani, K., Goodarzi, S. \& Tahghighi Ahmadi, N. (2017). The Concept of Love among Multi-cultures Postgraduate Students at Universiti Teknologi Malaysia. New Trends and Issues Proceedings on Humanities and Social Sciences. [Online]. 02, pp 88-96. Available from: www.prosoc.eu

\section{Introduction}

Love is a crucial requirement for the human soul. One needs to love and be loved as much as one needs to eat, drink, sleep and take a rest. A balanced life has love enters, and will manifest itself through harmonious relationships with others. Love is a human being's natural tendency towards an object that provides great pleasure. It is a magnetism that pulls one towards another.

However, the new generation seemed to look at love from a narrow perspective, which is limited primarily to the relationship between men and women. The love of fellow human to environment is largely absent. Love is more than a basic instinct as taught by modern science, which is rooted of our essence and development, encompassing all aspects of human behavior patterns.

Each day we are hearing people around us say "I love you" but in the true sense they may not know what the word truly means. Love is the most important word in the English language and abstract but at time also be able confuse. It has been given countless meanings, explanations, interpretations, and conceptions which usually refer to interpersonal feeling such as an experience felt by a person for another person.

According to the Oxford (2010), "love is an emotion of strong affection and personal attachment." In addition to above, love has some specific meanings in demographic factors such as different cultures or religions and even different concepts between male and female. Demography factors are those relating to personal characteristics like age, gender, education level, marital status, religion, culture, and occupation.

A meaningful aspect of university life is the opportunity to meet and interact with people from different cultures and religions. These intercultural interactions and relationships are reliant upon multiple types of cultures knowledge, including the beliefs, feelings and practices that people have about basic human needs such as love and affection.

Understanding how people from different cultures communicate love and affection in their close relationships is becoming an increasing focus for research. Given that affection is regarded as a fundamental human need understanding how people are similar or different in the way they think about, feel and express love is important for understanding how intercultural relationships are formed and continued in interactions (Floyd, 2006; Schultz, 1958).

The purpose of this study was to build upon existing research using inductive methods to identify culture similarities in knowledge about communicating love in their close relationships, and in finding out the concept of love in different cultures like Iranian, Malay, Chinese and Indian among postgraduate students at UTM.

\section{Background of the Study}

For realizing the status under which similarities and differences in the meaning and the reported experience of love may occur, a cultural view is crucial. A modern perspective on culture itself is the thing that is needed. Cultural distinctions are not ordinary changes reacting a biological core. These differences suggest visions to qualitatively different perspectives about love that have raised and erupted against various societies and in the same society at various historical periods. 
Mahabadi Ashtiani, K., Goodarzi, S. \& Tahghighi Ahmadi, N. (2017). The Concept of Love among Multi-cultures Postgraduate Students at Universiti Teknologi Malaysia. New Trends and Issues Proceedings on Humanities and Social Sciences. [Online]. 02, pp 88-96. Available from: www.prosoc.eu

The concept of love based on Iranian culture

Thus the notion of love in the ancient Persian Culture dates to pre-Zoroastrian era, devoted to love in the medieval Persian culture, where it is proposed that:

The Persian culture introduces many symbols of the passion and love such as Rumi, Hafiz and Sa'di. Everything is included by love and all is for love in the Persian culture which starts from loving friends and family, husbands and wives, and eventually walking in the war of elevated or divine love that is the ultimate goal in life.

Best on Sa'di that is one of the famous poets in Iran and in the world, about more than seven centuries ago wrote:

"The children of Adam are limbs of one body/ Having been created of one essence.

When the calamity of time afflicts one limb/ The other limbs cannot remain at rest.

If you have no sympathy for the troubles of others/ You are not worthy to be called by the name of "man."

Having many celebrations and being happy is one of the characteristics of Iranian people. They celebrated different days with happy and spent time. The culture, lifestyle, mood and the whole philosophy of life have reflected by these celebrations in ancient Iranian world. In the twenty first century BC there was a day in ancient Iran called "Day of Love", that is different from the Romans three centuries after Christ.

They called these days "SpandarMazgan". There was a philosophy in ancient Persia for calling this day as "love day", The national name of earth was The "SpandarMaz" that means developing the sacred, modest, and ideal that is only for God and the fifth day was "SpandarMaz" that is an icon for love, because with modesty, docility and passed to all love and sees all same and keep all nicely same as a mother.

"SpandarMazgan" was the icon of love in ancient Iranian culture. Women in this day to love their husband were away. Men, give their power to their wives and girls and given to them prizes and serve them.

\subsection{The concept of love based on Malay culture}

Islam is the foundation of translating the concept of love in Malay culture. Love in Islam can be in some different levels that it derives from:

i. Love to Allah

Islam lays love superlative in human life, namely love of God. Without love to God, slave performances aren't giving return which meant, whereas what become root to Islam is known and love God.

\section{ii. Love to prophets}

When God send his torch bearers to teach people how to go along the true way, the human had been in the darkness. it is stated the Rasulullah s.a.w is the torchbearer. after that, it changed to an obligation to any person that is called Muslim reveal his love to Rasulullah and all of the prophets' to pursue all admirable nature, because that love feeling, many friend willing to purism life and make the physical part of human respectively as a shield sake of defending quite Rasulullah s.a.w try to develop Islamic faith. 
Mahabadi Ashtiani, K., Goodarzi, S. \& Tahghighi Ahmadi, N. (2017). The Concept of Love among Multi-cultures Postgraduate Students at Universiti Teknologi Malaysia. New Trends and Issues Proceedings on Humanities and Social Sciences. [Online]. 02, pp 88-96. Available from: 
Mahabadi Ashtiani, K., Goodarzi, S. \& Tahghighi Ahmadi, N. (2017). The Concept of Love among Multi-cultures Postgraduate Students at Universiti Teknologi Malaysia. New Trends and Issues Proceedings on Humanities and Social Sciences. [Online]. 02, pp 88-96. Available from: www.prosoc.eu

It is found by Dion and Dion (1996) that young adult university students from a Chinese backgrounds and other Asian backgrounds confirmed that a "love as friendship" type greater than did the students of Anglo-Celtic or European ethnic cultural backgrounds.

The concept of love based on Indian culture

True love is not possible between individuals, claimed Anandamayi Ma, Genuine; true and permanent fulfillment is only through the love of God. "God" here means Brahman, the One that is our Self; all these are based on Wirth (2007).

In India sages say "Our 'human loves' don't quite merit the word love", according to explanation of Wirth (2007). They also suggest concepts such as attraction, dearly, fondness, infatuation, friendship, even delusion for our love-feelings, due to the involvement of egoistic intentions.

Developing love for God in India is common and important based on Wirth (2007). After all, life is meant to find the truth, and there are crucially two ways:

i. Jnana, which means knowledge or wisdom. In Jnana the major item is to be aware of the one limitless being, to be aware of the oneness, to identify with it, and to deny the reality of the manifold appearances radically and continuously.

ii. Bhakti, which means devotion. The major factor here is to develop a love for God, for one's true self, and to dissolve in it.

"In both cases the goal is the disappearance of the ego according to Wirth (2007). Sri Krishna says, The Bhakti path is easier. He recommends Arjuna: "Love me" because he is aware that the human being wants a tangible component for love,. Or love Rama, Shiva, and the divine Mother; or love Jesus, Buddha, and so on".

"Not all Indians strive so dedicatedly for Bhakti, because the attractions of the world are strong also in India", said Wirth (2007). Despite their contemporaries in the West, in the romantic love among a man and a woman, Indians don't expect heaven on earth. Thus, they don't pay strong attention to falling in love, and don't force themselves to do their beloved desires. They don't surely attempt to get close to the man or woman that they have tendency to him or her".

"In India, people have not thoroughly put away their old custom yet and the wisdom including in it, some of them are doing it eagerly, Wirth (2007) said. Many Indians are still well rooted in life at the moment. Indian people still know that they have to look to which place for pleasure and love in themselves".

According to Wirth (2007), in India Indian people believe the dream of eternal love is not foolish or unrealistic. In fact, love is so close, so real, that it is quite amazing and love is not outside, but deep inside.

\section{Method}

\subsection{Participants and procedure}

This study identifies the level of understanding on the concept of love among multi-cultures postgraduate students. Participants of this study were postgraduate students currently studying at Universiti Teknologi Malaysia (UTM), Johor Bahru campus. Purposive sampling method was used to select the sample. Firstly, participants were chosen based on the purposive sampling method. They comprised of thirty participants who subscribed to four main cultures, i) Iranian, ii) Malay, iii) Chinese and iv) Indian. Secondly, they were divided into four different groups consisting of ten respondents for each group. They were given a set questionnaire to be answered individually. 
Mahabadi Ashtiani, K., Goodarzi, S. \& Tahghighi Ahmadi, N. (2017). The Concept of Love among Multi-cultures Postgraduate Students at Universiti Teknologi Malaysia. New Trends and Issues Proceedings on Humanities and Social Sciences. [Online]. 02, pp 88-96. Available from: www.prosoc.eu

\subsection{Instrument}

An open-end questionnaire was used for the purpose of this study. Part $A$ of this questionnaire consisted of the demographic information. Part B consisted of items related to participants' view points on the concept of love in their culture among the forty postgraduate students.

\subsection{Data analyze}

Data collected were coded and analyzed using the SPSS for Windows version 15. Data were coded based from participants' responses to the items posed in relation to the concept of love. Percentages were used to describe the data.

\section{Finding}

\subsection{Questionnaire results}

Table 1. Summary of Respondents Based on Iranian culture

\begin{tabular}{ccc}
\hline NO & Feature & Percentage (\%) \\
\hline 1 & Like each other & 40.0 \\
2 & Care each other & 30.0 \\
3 & sacred & 50.0 \\
4 & Responsibility & 30.0 \\
5 & Feeling & 60.0 \\
6 & emotionally & 80.0 \\
7 & Sacrifice and & 50.0 \\
& devotion \\
\hline
\end{tabular}

Table 1 shows summary of respondents that answer to the concept of love based on Iranian culture. As can be seen in table 4.1 , four out of ten (40\%) students said that the concept of love is "like each other", three out of ten (30\%) students mentioned that the concept of love is "care each other", five out of ten (50\%) believed that is "sacred and holly sense", three out of ten (30\%) students mentioned that is" responsibility", six out of ten (60\%) said that is "feeling emotionally", eight out of ten $(80 \%)$ students cited that is "sacrifice and devotion" and five out of ten (50\%) students believed that the concept of love is "good manner" such as honest, troth and respect.

Table 2. Summary of Respondents Based on Malay culture

\begin{tabular}{ccc}
\hline NO & Feature & Percentage (\%) \\
\hline 1 & Like each other & 50.0 \\
2 & Care each other & 30.0 \\
3 & Be happy & 20.0 \\
4 & Responsibility & 60.0 \\
5 & Feeling emotionally & 30.0 \\
6 & Appreciation & 70.0 \\
7 & Good manner & 50.0 \\
\hline
\end{tabular}

Table 2 illustrates summary of respondents that answer to the concept of love based on Malay culture. As can be seen in table 4.2, five out of ten (50\%) students supposed that the concept of love is "like each other", three out of ten (30\%) students said that the concept of love is "care each other", two out of ten (20\%) believed that is "be happy", six out of ten $(60 \%)$ students mentioned that is" 
Mahabadi Ashtiani, K., Goodarzi, S. \& Tahghighi Ahmadi, N. (2017). The Concept of Love among Multi-cultures Postgraduate Students at Universiti Teknologi Malaysia. New Trends and Issues Proceedings on Humanities and Social Sciences. [Online]. 02, pp 88-96. Available from: www.prosoc.eu

responsibility", three out of ten (30\%) supposed that is "feeling emotionally", seven out of ten (70\%) students cited that is "appreciation" and five out of ten (50\%) students believed that the concept of love is "good manner" such as honest, troth and respect.

Table 3. Summary of Respondents Based on Chinese culture

\begin{tabular}{ccc}
\hline NO & Feature & Percentage (\%) \\
\hline 1 & Like each other & 40.0 \\
2 & Care each other & 40.0 \\
3 & Be happy & 20.0 \\
4 & Responsibility & 50.0 \\
5 & Sacrifice & 50.0 \\
6 & Commitment and Loyalty & 80.0 \\
7 & Good manner & 30.0 \\
\hline
\end{tabular}

Table 3 shows summary of respondents that answer to the concept of love based on Chinese culture. As can be seen in table 4.3 , four out of ten (40\%) students believed that the concept of love is "like each other", four out of ten (40\%) students said that the concept of love is "care each other", two out of ten (20\%) believed that is "be happy", five out of ten $(50 \%)$ students mentioned that is" responsibility", five out of ten (50\%) said that is "sacrifice", eight out of ten (80\%) students cited that is "commitment and loyalty" and three out of ten (30\%) students believed that the concept of love is "good manner" such as honest, troth and respect.

Table 4. Summary of Respondents Based on Hinduism

\begin{tabular}{ccc}
\hline NO & Feature & Percentage (\%) \\
\hline 1 & $\begin{array}{c}\text { Like each } \\
\text { other } \\
\text { Care each } \\
\text { other } \\
2\end{array}$ & 60.0 \\
3 & Honest & 60.0 \\
4 & Different & 70.0 \\
5 & types & 50.0 \\
Love is life & 80.0 \\
\hline
\end{tabular}

Table 4 shows summary of respondents that answer to the concept of love based on Indian culture. As can be seen in table 4.4 , six out of ten $(60 \%)$ students said that the concept of love is "like each other", six out of ten (60\%) students believed that the concept of love is "care each other", seven out of ten (70\%) cited that is "honest", five out of ten (50\%) students mentioned that is" vary for different types of relationship" and eight out of ten (80\%) mentioned that is "love is life".

\section{Conclusion}

Iranian postgraduate students mentioned that the concept of love in Iranian culture has these features: like each other's, care each other's, sacred and holly sense, responsibility, feeling emotionally, sacrifice and devotion and good manner such as be honest, truth and respect to each other's.

The most and highest point that Iranian believed is the concept of love is sacrifice and devotion for lover that this point supported by the notion of love in the ancient Persian Culture dates to pre-Zoroastrian era, devoted to love in the medieval Persian culture, where it is proposed that: 
Mahabadi Ashtiani, K., Goodarzi, S. \& Tahghighi Ahmadi, N. (2017). The Concept of Love among Multi-cultures Postgraduate Students at Universiti Teknologi Malaysia. New Trends and Issues Proceedings on Humanities and Social Sciences. [Online]. 02, pp 88-96. Available from: www.prosoc.eu

Everything is included by love and all is for love in the Persian culture which starts from loving friends and family, husbands and wives, and eventually walking in the war of elevated or divine love that is the ultimate goal in life.

Malay postgraduate students noted that the concept of love in Malay culture has these features: like each other's, care each other's, be happy each other's, responsibility, feeling emotionally, appreciation and good manner such as be honest, truth and respect to each other's.

The most feature that Malay believed that love is an appreciation that God has been given. This point supported by Islamic rules because Malay culture based on Islamic rules. Although new generation such as postgraduate students change a little some notions such as concept of love that this shows culture is changing.

As Sofia (2009), mentioned that Nowadays, Muslim people accept to change their mind to west occasions and have their life beside the issue that even prohibited in Muslim as one culture life due to the fact that any lifestyle or pattern more built up on mentality stated, especially about making love before marrying and during the period of engagement. Today this matter becomes an ordinary subject in Islamic societies and it is as same as other daily things.

Chinese postgraduate students believed that the concept of love in Chinese culture has these features: like each other's, care each other's, be happy each other's, responsibility, sacrifice, good manner such as be honest, truth and respect to each other's and one feature that Chinese postgraduate students believed that more is commitment and loyalty.

These features supported by Shaver, Wu, and Schwartz (1992) discovered that love had distinctive "hedonically negative" relationships in the Chinese description of love which they called "sad or painful love" in a research about emotion-related notions found in American English as opposed to modern Chinese.

Also a part of traditional Chinese culture based on Buddhist practice is these resemblances and contemplations. The foundation of Buddhist ethics is loving kindliness. Ideas and contemplations like these are not limited to those who follow the teaching of the Buddha and all true religions and spiritual customs spread this kind of commitment towards scattering welfare.

Although these features that found in this study a little difference with traditional Chinese culture because postgraduate students are new generation and these students tend to new culture as Yang (1986) mentioned that youth adults there were, really, now individualistic instead of collectivist, against the traditional picture of Chinese culture. Recently, Chinese students have the desire to have value orientation patterns same as American students patterns. And also Yang (1986), reason of this evolution or tend to new culture stated that this evolution started from a "social orientation" to an "individual orientation" that is against a more excellent description on self-expression and personal gratification.

Indian postgraduate students said that the concept of love in Indian culture has these features: like each other's, care each other's, be honest, vary for different types of relationship and one feature that they believed that more is love is life.

These features and belief that Indian postgraduate students said supported by "Our 'human loves' don't quite merit the word love", according to explanation of Wirth (2007). Indian sages also suggest concepts such as attraction, dearly, fondness, infatuation, friendship, even delusion for our love-feelings, due to the involvement of egoistic intentions.

And also supported by Wirth (2007), in India Indian people believe the dream of eternal love is not foolish or unrealistic. In fact, love is so close, so real, that it is quite amazing and love is not outside, but deep inside. 
Mahabadi Ashtiani, K., Goodarzi, S. \& Tahghighi Ahmadi, N. (2017). The Concept of Love among Multi-cultures Postgraduate Students at Universiti Teknologi Malaysia. New Trends and Issues Proceedings on Humanities and Social Sciences. [Online]. 02, pp 88-96. Available from: www.prosoc.eu

As can be seen "like each other's and care each other's" are similar features in all cultures that study in this research and the difference features among cultures before mentioned that are in Iranian culture the concept of means sacrifice and devotion for lover, in Malaysian cultures the concept of love is an appreciation that God has been given, in Chinese culture the concept of love means commitment and loyalty to lover and in Indian culture the concept of love means love is life.

\section{Recommendation}

The recommendations were based from the final finding of the interesting study on the concept of love among four different groups of postgraduate students who subscribed to four different cultures who were currently studying at Universiti Teknologi Malaysia. One of the main recommendations would be to provide more literature reviews on different cultures in the university library. Secondly is to provide more counselors with different background and religions to provide counseling services at the university counseling centre.

\section{References}

Dion, K. L. \& Dion, K. K. (1996). Chinese adaption to foreign cultures. The hand book of Chinese psychology.

Dion, K. K. D. K. L. (1996). Cultural perspective on romantic love. Person Relationships, 3.

Dion, K. L., \& Dion, K. K. .(1993). Individualistic and collectivistic perspectives on gender and the cultural concept of love and intimacy. Journal of Social, (49),53-69.

Floyd, K. (2006). Communicating affection: Interpersonal behavior and social context. Cambridge University Press.

Hsu, F. L. K. (1981). American and Chineses: Passages to differences (3 Ed.). Honolulu: The University Press of Hawaii.

Love in Iranian culture. from http://www.asemoni.com/human/love/sepandarmazgan.php Oxford. (2010). (3 ed.): University press

Schutz, W. (1958). FIRO: A three-dimensional theory of interpersonal behavior. New York: Rinehart.

Sofiah, N. (2009). Coupling and love before marriage. fromhttp://sesucicintamuyarabb.blogspot.com/2009/03/coupling-and-love- before-marriage 27.html

Wirth, M. (2007). Love in India. From http://www.lifepositive.com/Mind/Love/Love_in_India112007.asp

Wu, S. (1992). A comparison of American and Chinese conception of love.

Yang, K. S. (1986). Chinese personality and its change. The psychology of the Chinese people, 106-170. 